\title{
On the Construction of University Campus Culture under the Network Environment
}

\author{
Lehui Huang ${ }^{1, a}$, Xinxin Wang ${ }^{2, b}$ \\ ${ }^{1}$ Education School, Jiangxi Science \& Technology Normal University, Nanchang, China \\ ${ }^{2}$ Education School, Jiangxi Science \&Technology Normal University, Nanchang, China \\ aHLH8899@163.com; b1270731275@QQ.com
}

Keywords: network environment; university; campus culture

\begin{abstract}
The network is changing people's way of thinking and behavior, and it has also brought new opportunities and challenges to the campus culture after entering the campus. The paper mainly discusses the opportunities and challenges in the construction of campus culture in university under the network environment, and puts forward suggestions.
\end{abstract}

\section{Introduction}

The network, as a new tool of information transmission and interpersonal communication, is entering into the campus with rapid development momentum. The network has brought far-reaching impact in students' ideas, learning styles, life way and mental healthy, and shown positive and negative coexistence state. Studying how to promote the construction of campus culture in colleges under the network environment has become a practical problem that we should face seriously. It has important significance to implement the party's education policy better, establish and implement the scientific outlook on development, enrich campus culture life, improve the students' ideological and moral quality and promote college students' all-round development.

\section{New opportunities brought by the network to the university campus culture construction}

The network enriches the thought resources of campus cultural construction. With the network media, the information updates fast and the contents are rich, which is greatly superior to the traditional media. As long as we master the network can we find endless information we need.

The network provides a new effective carrier of campus culture construction. Under the network environment, abundant network information makes the way of acquiring information change fundamentally. Before, students acquire information mainly through the traditional media and teachers' preaching and imparting knowledge. At present, students are more interested in obtaining information through the network. The contents about campus culture published by colleges on the campus not only have sound and picture, but also make up for the defects of dull content and a lot of manpower and material resources, which creates a new world of university campus culture construction and provides a new carrier of culture for deepening the construction of college campus culture.

The network enhances the radiation force of campus culture propaganda. The network provides equal cultural participation opportunities for people to make them bold personal views and express real idea in the quasi open network space, so as to achieve the thought collision and intersection. The openness of principal mailbox and campus forum in many colleges makes the teachers and students achieve zero distance contact with the schoolmaster and participate in exchange and communication of campus forum through interactive function of the network.

The network provides broader platform for colleges to carry out the construction of campus culture. The network extends the students' thought out of the campus and brings into wide social space, to make up for the shortcomings of the original coverage of campus culture. Hosting a series of campus cultural activities on campus network can attract the public to participate and exchange across time and space, so as to make people update ideas and broaden knowledge. 


\section{The challenges of the construction of university campus culture under the network environment}

The development of the network creates new environment for playing the function of college campus culture and expands new channels and methods in the construction of campus culture, to make the campus culture have significant influence in education. However, the network is a "double-edged sword", which determines it has dual nature on campus culture. In another word, it also brings some problems to the construction of campus culture.

The virtual social environment in the network environment will bring direct infringement to the personality of college students. Network information is complex and changeable, so it easily causes the students with weak psychological and spiritual capacity to produce anxiety and impatience. Along with single, closed and conceal man-machine communication, students' character tend to be lonely and melancholy, and they will become unconcerned with the collective and others. Some students dress as a man or a woman in clothing, which will also lead to gender identity and psychological distortion, loss of healthy and normal ethical relationship.

The negative elements in the network environment may damage the moral sentiments of college students. In the network, some students talk about some bad-taste and poor-style topic; some students often violate the school rules; individual students even induce the case or accident. More serious is, some students don't think lying in the internet is immoral behavior and hold that they can do what they want without scruple. These fuzzy and wrong ideas easily cause college students' emotion changing, responsibility weakening and moral landslide.

Disorder of network use will lead to that college students suffer from network disease. Studies have shown that, if people surf the web for long time, dopamine level in the brain will increase substantially, make them indulge in the network virtual world and produce serious sense of decadence and frustration, and then gradually lead to psychological and physiological abnormalities. Such as the human body biological clock disorders, slow thinking, loss of appetite, etc.

\section{The countermeasures of campus culture construction in university under the network environment}

Strengthen the construction of spiritual culture and enrich the connotation of university campus culture. Spiritual culture, the core of campus culture, embodies the school values and is the direction and the essence of campus culture. In the network environment, school should pay attention to the construction of spiritual culture to lay the foundation for the construction of harmonious campus. First, sharp the university spirit advancing with the times. Take the campus network as a platform to cultivate teachers and students' scientific spirit, democratic spirit, humanistic spirit, innovative spirit and rational critical spirit, so as to strengthen their sense of social responsibility and historic mission. Second, advocate humanistic spirit of harmony. Without the humanistic spirit of harmony, network technology is possible to lead the young students to evil ways. School should integrate the network technology with humanity education and carry out a wide range of network cultural activities that college students like to see and hear. Cultivate students' sentiments with humanistic spirit and train their emotion to resist the infringement of bad ideas on the internet.

Strengthen the moral responsibility education and shape the college students' network moral personality. First of all, pay attention to cultivating students' network quality and enhancing the recognition ability of network culture, so as to make them identify the authenticity of network information and treat them with rational thinking. Secondly, strengthen the sense of moral responsibility education to improve students' self-cultivation and self-discipline when surfing the internet. Don't peek and destroy the network system on the internet to develop network moral awareness, moral will and moral responsibility; guide them to establish the correct network morality and consider the internet as a source of knowledge and learning means rather than a way to hunt for bad information, so as to make them adjust and manage themselves, correctly treat the man-machine relationship and the difference between the virtual space and realistic space, improve 
the ability of self-discipline, thus shaping the healthy moral personality.

Strengthen the network hardware facilities to provide the material basis for the construction of college campus culture. Material culture is the basis of the campus culture and the carrier of realizing the campus culture construction. Constructing campus culture in colleges and universities under the network environment needs to strengthen the network hardware facilities construction. First, strengthen the construction of campus network system. The level of network hardware system directly affects the process of campus informatization and relates with the forming and development of campus network culture. Second, create good campus network cultural atmosphere. Use the campus network system to develop comprehensive subject education websites with healthy contents and various forms; guide students' ideological consciousness through electronic bulletin board, chat rooms, electronic mail, special columns and other forms. Strengthen the construction of campus culture while creating good campus cultural environment of the network.

Strengthen the monitoring and management of the internet and reduce the information pollution to students. Social network provides people with great freedom exceeding the scope of existing social moral and legal standards, thus the school must intensify the management of the internet. The colleges should establish permanent mechanism for network information management to coordinate online information management, and set the management rules and regulations.

\section{Conclusion}

The network is the characteristic of the development of the times, and plays an important role in the construction of campus culture. As an important place cultivating the elite of the times, the university should strengthen the construction of spiritual culture and enrich the connotation of university campus culture, enhance the moral responsibility education and shape the college students' network moral personality, and improve the network hardware facilities to provide the material basis for the construction of college campus culture, so as to create good cultural environment for completing the education goal and cultivate high quality talents.

\section{References}

[1] Jianjun Xu. The theory and method of college students' network ideological and political education[M]. People’s publishing house, 2010.

[2] Zhongxiao Liu. The construction of college network culture in the perspective of harmonious campus[J]. Guangming Daily, 2012.

[3] Chengxue Yu. On the impact of campus culture on college students' value[J]. Theoretical frontiers, 2005(5).

[4] Ming Gao. Path selection of the campus culture construction in the view of network culture[J]. The school party construction and ideological education, 2007(6):70-71.

[5] Aifeng Kong. Thinking of college network culture construction in the perspective of harmonious campus[J]. Chinese Journal Web, 2010.

[6] Baohong Zhang. The influence and countermeasures of the network environment on college students’ ideological and moral education[J]. Inner Mongolia TV University Journal, 2004(1).

[7] Chunyi Liang. Thinking on campus culture construction under the network environment[J]. Education guide, 2005(9):42-43. 